\title{
Effect of Trigonella foenum gracecum (Fenugreek) Seed Extract in Experimentally Induced Gastric Ulcer in Wistar Rats
}

\author{
Shreelakshmidevi Singaravelu ${ }^{1,5^{*}}$, Jaikumar Sankarapillai ${ }^{2}$, Abilash Sasidaran Chandrakumari ${ }^{3,5}$, Pammy Sinha ${ }^{4}$
}

\section{Shreelakshmidevi Singara- velu ${ }^{1,5^{*}}$, Jaikumar Sankara- pillai ${ }^{2}$, Abilash Sasidaran Chandrakumari ${ }^{3,5}$, Pammy Sinha ${ }^{4}$}

\section{'Department of Pharmacology, Shri Sathya Sai Medical College and Research Institute, Sri Balaji Vidyapeeth, Chennai, Tamil Nadu,INDIA. \\ ${ }^{2}$ Department of Pharmacology, Sri Lakshmi Narayana Institute of Medical Science Medical College and Hospital, Puducherry, INDIA. \\ ${ }^{3}$ Department of Pathology, Shri Sathya Sai Medical College and Research Institute, Sri Balaji Vidyapeeth (DU), Chennai, Tamil Nadu,INDIA. \\ ${ }^{4}$ Department of Pathology, Sri Lakshmi Narayana Institute of Medical Science Medical College and Hospital, BIHER Puducherry, INDIA. \\ ${ }^{5}$ Research scholar, Bharath Institute of Higher Education and Research, Chennai, Tamil Nadu, INDIA. \\ Correspondence \\ Dr. Shreelakshmidevi Singaravelu \\ Department of Pharmacology, \\ Shri Sathya Sai Medical College and Research Institute, Sri Balaji Vidyapeeth (DU), Chennai, Tamil Nadu, INDIA. \\ Phone no : +91 9894187944 \\ E-mail: drshree20@gmail.com \\ History \\ - Submission Date: 14-06-2018; \\ - Review completed: 07-07-2018; \\ - Accepted Date: 07-08-2018}

DOI : 10.5530/pj.2018.6.200

Article Available online

http://www.phcogj.com/v10/i6

Copyright

(C) 2018 Phcog.Net. This is an openaccess article distributed under the terms of the Creative Commons Attribution 4.0 International license.

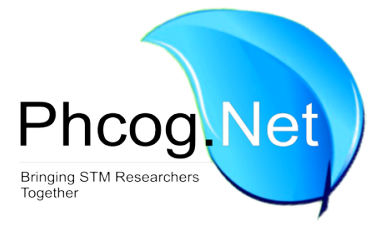

\begin{abstract}
Background: Trigonella foenum graceum (Fenugreek) seeds are commonly used in India as traditional medicine for Diabetes, Dysmenorrhea, lactation and arthritis. The gastro-protective role of Fenugreek seeds are yet to be explored. Objectives: To evaluate the effect of Fenugreek seed extract in Indomethacin induced gastric ulcer models. Materials and Methods: Albino wistar rats were divided into five groups with eight animals in each. Gastric ulcer was induced using Indomethacin $20 \mathrm{mg} / \mathrm{Kg}$. Fenugreek at dose of $200 \mathrm{mg} / \mathrm{Kg}$ and $400 \mathrm{mg} / \mathrm{Kg}$ was administered to group III, IV and group V received Rantidine $30 \mathrm{mg} / \mathrm{Kg}$. Ulcer index, volume of gastric juice and acidity was estimated. To study the anti-oxidant property the level of catalase, SOD, GST and T. Bars were done. Results: Fenugreek treated group III showed a significant decrease in ulcer index, volume of gastric juice and acidity when compared to control positive group II. Oxidative enzyme study indicated a significant increase in Catalase, SOD and GSH value in treated group when compared with control positive group II and significant decrease in T. Bars value in treated group. Conclusion: Fenugreek seed extract has both gastro-protective and Anti-oxidant property.
\end{abstract}

Key words: Gastro-protection, Fenugreek, Indomethacin, seed-extract, Ulcer inhibition.

\section{INTRODUCTION}

India is facing an era of faster lifestyle and unhealthy diet. In this current scenario Gastric ulcer stands out as a detrimental problem in the society. Point prevalence of gastric ulcer in India is $4.72 \%$ and lifetime prevalence is $11.22 \% .{ }^{1}$ Western studies reveal that $5-10 \%$ of adult populations are more prone for gastric ulcer. The prevalence of gastric ulcer is more discernible in regions where there is increased consumption of sloppy food like cooked rice, Tapioca, sattoo, sambar and buttermilk. ${ }^{2}$ These foods can be easily gobbled down without getting chewed, thus mixing of saliva is reduced. The other factors for high gastric ulcer rate in India are chewing betal nut, tobacco, smoking and faster competing lifestyle.

Gastric ulcer generally presents with abdominal discomfort, loss of appetite, hematemesis, nausea, vomiting and dark colored stool. Peptic ulcer is more common among middle age and older adults. Trigonella foenum graceum is called as fenugreek; its seeds are used commonly in Indian medicine system to treat many gastrointestinal disorders. ${ }^{3}$ Lysine and L- tryptophan are the active alkaloids found in fenugreek. It contains mucilage and galactomannans used in protection of gastric mucosa. Fenugreek seeds have inhibitory action on the secretion of hydrochloric acid from parietal cells of stomach. It reduces lipid peroxidation which plays major role in inflammation of gastric mucosa. The beneficial role of fenugreek seed in diabetics and hypercholosteremia is well studied. ${ }^{4-5}$ But their role as an antiulcer agent is not adequately studied. Thus the current study is proposed to evaluate the effect of Trigonelle foenum graceum seed extract on experimentally induced gastric ulcer in Wistar rats.

\section{MATERIALS AND METHODS}

Forty wistar albino rats weighing 130-150 g were used in the study. The study was approved by Institutional Animal Ethical Committee. Animals were housed at a temperature of $24 \pm 2^{\circ} \mathrm{C}$ and relative humidity of $30-70 \%$. The animals were fed with staple pellet diet from Hindustan Lever Ltd., Mumbai. Fenugreek seeds were obtained from agricultural market center; it was identified and authenticated by Botanical survey of India, Southern regional Centre, Tamil Nadu Agricultural University, Tamil Nadu.

Rantidine tablets were purchased from Glaxo Smithkine Ltd. Each tablet contained 150mg of Ratidine hydrochloride. It was dissolved in distilled water at dose of $30 \mathrm{mg} / \mathrm{Kg}$ and was administered orally with the help of gastric tube.
Cite this article: SingaraveluS, SankarapillaiJ, ChandrakumariAS, SinhaP. Effect of Trigonellafoenum gracecum (Fenugreek) Seed Extract in Experimentally Induced Gastric Ulcer in Wistar Rats. Pharmacog J. 2018;10(6):1169-73. 


\section{Preparation of Fenugreek seed aqueous Extract}

About 25g of fenugreek seed were crushed and powdered. Fenugreek seed powder was extracted with $500 \mathrm{ml}$ of boiling distilled water for about $5 \mathrm{~min}$. The decoction was allowed to cool for $30 \mathrm{~min}$ then subjected to double filtration and stored in refrigerator.

\section{Screening of antiulcer property}

The Albino wistar rats were fed with basal diet and observed for normal activities. The rats were divided as at random into five groups with eight rats in each. Normal control group was fed on pellet diet and water at libidum. The other four groups were given oral dose of indomethacin $20 \mathrm{mg} / \mathrm{kg}$ in $0.1 \%$ tween 80 solutions to induce gastric ulcer. The four groups were divided as treated and non-treated groups. The non-treated group received intragastric administration of only indomethacin. The other three treated group received fenugreek seed extract $200 \mathrm{mg} / \mathrm{kg}$ orally, fenugreek extract $400 \mathrm{mg} / \mathrm{kg}$ orally and Rantidine $30 \mathrm{mg} / \mathrm{kg}$ orally. After six weeks of study blood samples were collected for estimation of hemoglobin and packed cell. The rats were sacrificed. The gastric juice was collected by ligating the pyloric and fundic end of the stomach. $3 \mathrm{ml}$ of distilled water was injected then the gastric juice was collected in the test tube and subjected to centrifuge for $500 \mathrm{rpm}$ for $5 \mathrm{~min}$. The total acidity of gastric juice and volume was measured using a graduated cylinder. ${ }^{6}$ The decrease in gastric juice volume was calculated using the formula by Pasrmar and Desai. ${ }^{7}$

$$
\text { Percentage of decrease in gastric juice }=\frac{\begin{array}{l}
\text { Volume of gastric juice in control positive }(-) \\
\text { Volume of gastric juice in treated group }
\end{array}}{\text { Volume of gastric juice in control positive }} \times 100
$$

The stomach were opened along the greater curvature and washed with saline. The length of each gastric ulcer was measured to determine the ulcer Index (UI) and curvature ratio, ${ }^{7}$ Depending on the severity of gastric mucosal lesion they scaled from $1-3 ; 1=$ less than $1 \mathrm{~mm}, 2=1$ to $2 \mathrm{~mm}, 3=$ greater than $2 \mathrm{~mm}$. the overall total was divided by factor of 10 , which was designated as Ulcer index.

Length of gastric ulcer in control positve group $(-)$
Curative ratio $=\frac{\text { Length of gastric uler in treated group }}{\text { Length of gastric ulcer in control positive group }} \times 100$

The mucosa of glandular stomach was removed by scraping with knife and $10 \%$ homogenate was prepared for estimation of antioxidantsGlutathione (GSH) by Moron et al. ${ }^{8} \mathrm{~T}$ Bars by Ohkawa et al. ${ }^{9}$ Catalase by Aebi $\mathrm{HE}^{10}$ and Superoxidase dismutase by Mc Cord and Fridovich. ${ }^{11}$

Table 1: Mean value \pm SD of body weight gain in experimental rat groups.

\begin{tabular}{cccccc}
\hline WEIGHT & GROUP I & GROUP II (Control & GROUP III (Fenugreek & GROUP IV (Fenugreek & GROUP V (Rantidine \\
& (Control) & positive) & 200mg) & 400mg) & 30mg/kg) \\
\hline INITIAL WEIGHT(gm) & $139 \pm 4.44$ & $139.25 \pm 4.71$ & $139.75 \pm 4.59$ & $138.37 \pm 5.15$ \\
FINAL WEIGHT(gm) & $188.31 \pm 4.99$ & $175.12 \pm 7.60$ & $185.25 \pm 4.13$ & $181.37 \pm 5.62$ & $139.62 \pm 5.26$ \\
\hline
\end{tabular}

Table 2: Mean value \pm SD of gastric parameters in experimental rat groups.

\begin{tabular}{cccccc}
\hline Group variable & $\begin{array}{c}\text { GROUP I } \\
\text { (Control) }\end{array}$ & $\begin{array}{c}\text { GROUP II (Control } \\
\text { positive) }\end{array}$ & $\begin{array}{c}\text { GROUP III (Fenugreek } \\
\text { 200mg) }\end{array}$ & $\begin{array}{c}\text { GROUP IV (Fenugreek } \\
\text { 400mg) }\end{array}$ & $\begin{array}{c}\text { GROUP V (Rantidine } \\
\text { 30mg/kg) }\end{array}$ \\
\hline $\begin{array}{c}\text { Decrease in volume of } \\
\text { gastric juice (\%) }\end{array}$ & -- & -- & $33.87 \pm 14.11$ & $23.34 \pm 27.25$ \\
$\quad \begin{array}{l}\text { Ulcer index (mm) } \\
\text { Total acidity of gastric } \\
\text { juice }\end{array}$ & -- & $23.40 \pm 1.09$ & $12.56 \pm 0.78$ & $12.95 \pm 1.18$ & $38.73 \pm 14.06$ \\
& $0.13 \pm 0.05$ & $0.39 \pm 0.10$ & $0.19 \pm 0.01$ & $0.21 \pm 0.01$ \\
\hline
\end{tabular}

\section{Statistical Analysis}

Data was collected and analyzed using IBM statistical package for social science (SPSS) software version 21 . The data's were presented in mean \pm standard deviation and " $t$ " test was used for statistical significance.

\section{RESULTS}

A total of 40 albino wistar rats were selected. They were divided into five groups; group I- normal control group, group II- drug induced non treated group, groups III, IV- drug induced fenugreek treated groups and group V- drug induced Rantidine treated group.

Data in Table 1 indicated the initial and final weight of the rats. Figure 1 illustrated the percentage of weight gain which were significantly decreased at $p<0.01$ in control positive group III compared with normal control group I. Group III,IV and V should a significant increase in final weight and weight gain compared with control positive group II.

Figure 2 shows that the volume of gastric juice was significantly increased in control (+) group II at $P<0.001$ compared with normal control group I. The results in Table 2 showed the various properties of gastric ulcer. The total acidity of gastric juice was significantly increased in control positive group II at $p<0.001$ when compared to normal control group I. The total acidity of gastric juice of group III, IV and V significantly decreased at $p<0.001$ when compared with control positive group II. The volume of gastric juice, total acidity and gastric ulcer index were significantly decreased in treated groups III, IV and V when compared with untreated control positive group II

The result depicted by Figure 3 shows the values of oxidative enzyme studies. It clearly indicates that the values of catalase, superoxidase dismutase, gastric glutathione were significantly increased in treated group III, IV and V when compared to untreated control positive group II at $p<0.001$.The value of T. Bars was significantly decreased in treated group III, IV and V when compared with untreated control positive group II at $p<0.001$.

Data of Table 3 displays the blood hemoglobin and packed cell value. It is evident that control positive group II shows a significant decrease in hemoglobin and PCV values when compared with treated group III, IV and $\mathrm{V}$ at $p<0.001$.

\section{DISCUSSION}

The study clearly shows that Indomethacin; a non-steroidal anti-inflammatory drug has induced gastric ulcer in the rodent model. Indomethacin acts by decreasing prostaglandin synthesis which attributes to increased gastric protection leading to gastric mucosal erosion. ${ }^{12-14}$ Adding on to 
Table 3: Mean value \pm SD of Blood $\mathrm{Hb}$ and PCV in experimental rat groups.

\begin{tabular}{|c|c|c|c|c|c|}
\hline $\begin{array}{l}\text { GROUPS } \\
\text { VARIABLE }\end{array}$ & $\begin{array}{l}\text { GROUP I } \\
\text { (Control) }\end{array}$ & $\begin{array}{l}\text { GROUP II (Control } \\
\text { positive) }\end{array}$ & $\begin{array}{c}\text { GROUP III (Fenugreek } \\
200 \mathrm{mg})\end{array}$ & $\begin{array}{c}\text { GROUP IV (Fenugreek } \\
400 \mathrm{mg} \text { ) }\end{array}$ & $\begin{array}{c}\text { GROUP V (Rantidine } \\
30 \mathrm{mg} / \mathrm{kg} \text { ) }\end{array}$ \\
\hline HAEMOGLOBIN (gm/dl) & $12.87 \pm 0.58$ & $8.6 \pm 0.42$ & $12.13 \pm 0.53$ & $11.87 \pm 0.58$ & $12.08 \pm 0.56$ \\
\hline
\end{tabular}

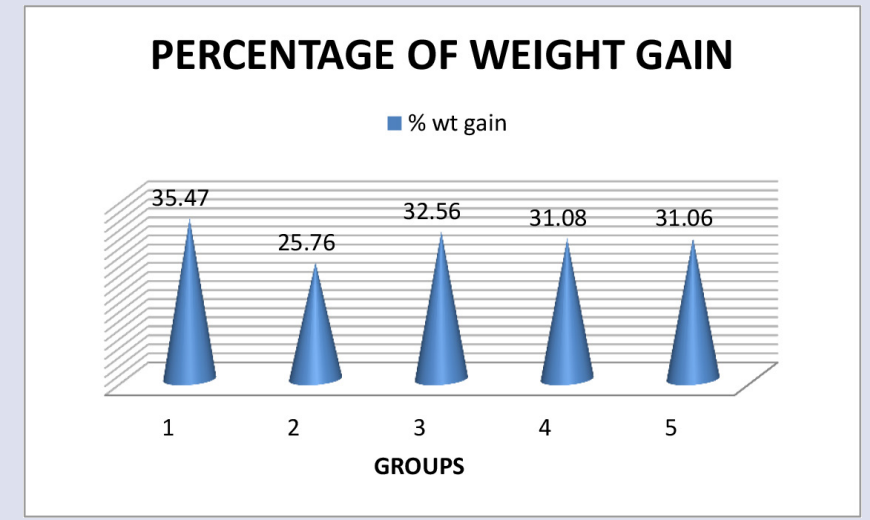

Figure 1: Percentage of weight gain.

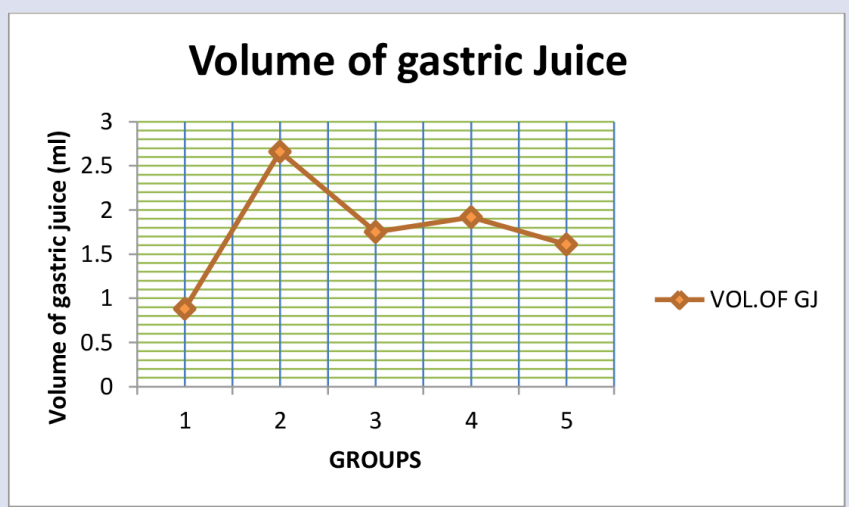

Figure 2: Volume of gastric juice of each animal in all five groups.

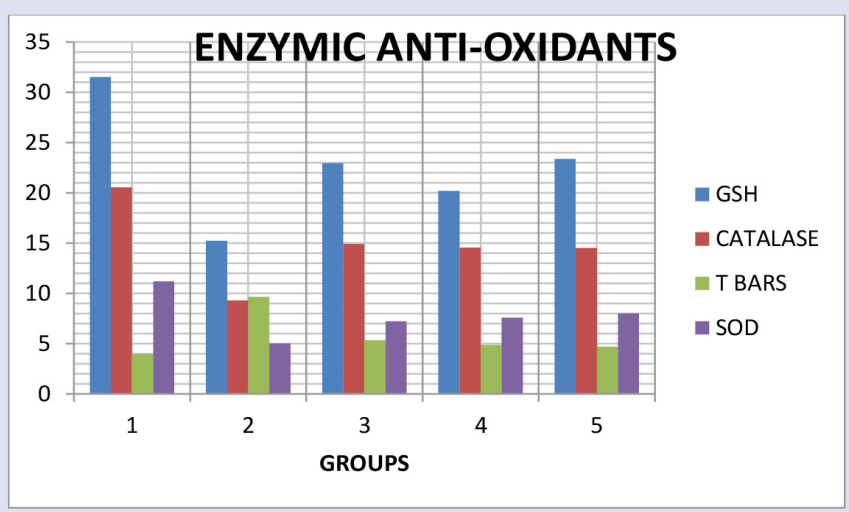

Figure 3: Level of Enzymic Anti-oxidants- Glutathione (GSH), catalase, T. Bars, superoxidase dismutase from gastric tissue homogenate.

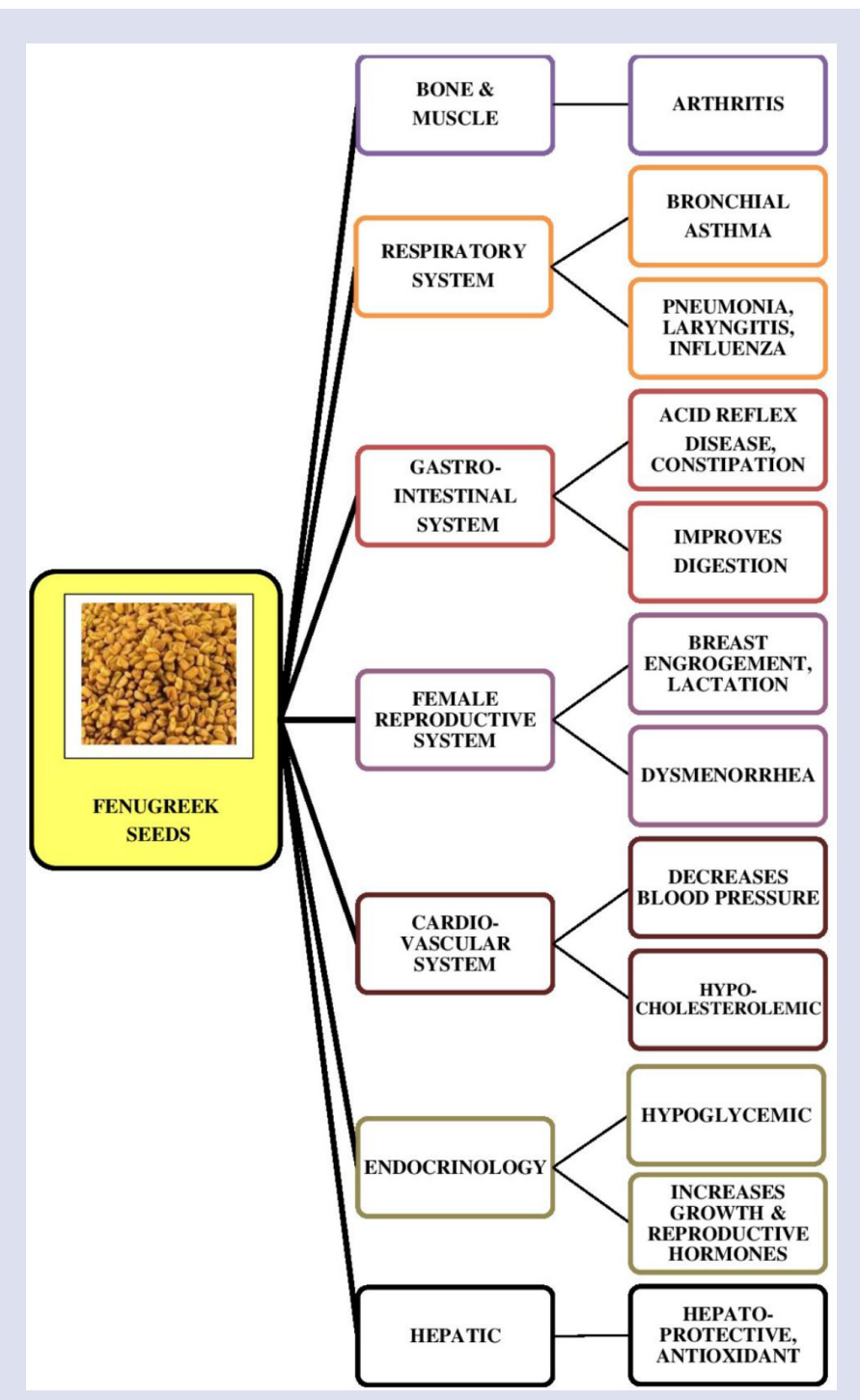

Figure 4: Traditional medical uses of Fenugreek seeds around the world.

it indomethacin also decreases antioxidant enzymes like Catalase, SOD and GST in the rat stomach. Understanding the ulcer inducing agents might be of utmost relevance in designing new antiulcer agents. Synthetic drugs are more susceptible for high toxicity and exorbitant cost, exploiting natural products which are less toxic, more affordable and efficacious can be more appropriate choice in treatment of gastric ulcer.

Fenugreek is used as both herb and spice in wider parts of India. Fenugreek seeds are commonly used for arthritis, acid reflex disorders, lactation, dysmenorrhea, breast engorgement, bronchial asthma, labour induction and treating hormonal disorders (Figure 4). Fenugreek seeds possess hypoglycemic effects by stimulating insulin synthesis and increasing the sensitivity of tissues to available insulin. The characteristic property is to 
reduce blood sugar level without the risk of developing severe hypoglycemia. ${ }^{15}$ Study by Kumari and Sinha showed that high fiber fenugreek diet is effective in management of diabetes. ${ }^{16}$ Bhatia et al. proved the protective effect of fenugreek on lipid peroxidation and on enzymic antioxidants. ${ }^{17}$ Studies by Priya V, et al. and Yadav et al. shows gastroprotective effect is one of the most noted effect of Trigonella foenum graceum. ${ }^{18-19}$

Fenugreek seed extract prevented the risk of lipid peroxidation by enhancing antioxidant potential of gastric mucosa which can be linked to its gastro-protective effect. ${ }^{20}$ The study by Nirajan Ghosal et al. proved gastro-protective effect of fenugreek enriched fraction against indomethacin induced gastric ulcer was by increasing the quantity and quality of mucin secretions. ${ }^{21}$ The current study clearly shows the effect of Fenugreek as antiulcer agents. The polysaccharide composition of fenugreek seeds forms a mucin like layer on the surface of gastric mucosa and acts as a barrier against the ulcer inducing agents and the exposure of endogenously formed acid and pepdin..$^{22}$ Brinal et al. stated that the crucial target for the fenugreek seeds by in silico analysis method was to antagonize $\mathrm{H}^{+} \mathrm{K}^{+}$ATPase pump and produce gastro-protective effect. ${ }^{23}$ Kheirandish et al. showed that oral administration of fenugreek seeds extract could protect intestinal mucosa against experimentally induced intestinal ischemia-reperfusion injuries in rats. ${ }^{24}$

In the current study hemoglobin and packed cell volume was maintained in fenugreek treated group when compared to control positive group were it was reduced. Fenugreek seed extracts are rich in polyphenol which protects the erythrocyte from oxidative damages. ${ }^{25}$ The present study results showed that gastric tissue damage and ulceration was produced due to Indomethacin effect. Fenugreek administration has resulted in protection against Indomethacin induced gastric damage through its antioxidant property and by reducing ulcer index, volume of gastric juice and acidity. This proves its efficiency as an antiulcer agent against Indomethacin induced gastric ulcer in rodent models. The major limitation of the study was that the studied was not extended to study the toxicities of fenugreek seed. Thus future research can add up to make fenugreek seed extract to become an effective antiulcer agent to treat NSAID induced gastric ulcer. Researches can also be extended to expect the full potential of fenugreek in the treatment of other types of gastric ulcer.

\section{CONCLUSION}

Fenugreek seed extract is rich in polyphenol which protects the erythrocyte from oxidative damage and maintains the hemoglobin and PCV values. The present study showed the potential therapeutic effects of fenugreek seed extract in Indomethacin induced gastric ulcer by its antioxidant and gastro-protective property.

\section{ACKNOWLEDGEMENT}

The authors herewith acknowledge Dr. Bala Murugan Velu, Professor of Microbiology, SLIMS, Puducherry for his continuous support and encouragement.

\section{CONFLICT OF INTEREST}

The authors declare no conflict of interest.

\section{ABBREVIATIONS}

UI: Ulcer Index; SOD: Superoxidase Dismutase; GSH: Glutathione; NSAID: Non Steroidal Anti-inflammatory Agents; PCV: Packed cell volume; Hb: Haemoglobin.

\section{REFERENCES}

1. Khuroo MS, Mahajan R, Zargar SA, Javid G, Munshi S. Prevalence of peptic ulcer in India: an endoscopic and epidemiological study in urban Kashmir. Gut.1989;30(7):930-4

2. Malhotra SL. Peptic ulcer in India and its aetiology. Gut.1964;5(5):412.

3. Puri D. Therapeutic potentials of Fenugreek. Indian journal of Physiology and Pharmacology. 1998;42(3):4223-424.

4. Sharma RD, Sarkar A, Hazra DK, Misra B. Hypolipidaemic effect of Fenugreek seeds: A chronic study in Non-insulin dependent Diabetic patients. Phytotherapy Research.1996;10(4):332-4.

5. Jelodar G, Maleki M, Motadayen M, Sirus S. "Effect of fenugreek, onion and garlic on blood glucose and histopathology of pancreas of alloxan-induced diabetic rats". Indian Journal of Medical Sciences. 2005;59(2):64-9

6. A.O.A.C. Official Methods of Analysis. $16^{\text {th }}$ Ed., Association of Official Analytical Chemists, Washington, DC. 1995.

7. Parmar NS, Desai JK. A review of the current methodology for the evaluation of gastric and duodenal antiulcer agents. Indian J Pharmacol.1993;25(3):120-35.

8. Moron, M.A., J.W. DePierre and B. Mannervick. Levels of glutathione, glutathione reductaseand glutathione-S-transferase activities in rat liver. Biochimica et Biophysica Acta. 1979;582(1):67-78.

9. Ohkawa H, Ohisi N, Yagi K. Assay for lipid peroxides in animal tissues by thiobarbituric acid reaction. Anal Biochem. 1979;95(3):351-8.

10. Aebi HE. Catalase. 2 Ed. In: Bergmeyer, H.U. (Ed.), Methods in Enzymatic Analysis, Verlagchemic. Weinheim. 1974;3:673-684.

11. McCord JM, Fridovich I. Superoxide dismutase, an enzymatic function for erythrocuprein (hemocuprein). J. Biological Chemistry. 1969;244(22):6049-55.

12. Corthout J, Pieters LA, Claeys M, Vanden-Berghe DA, Viletinck AJ. Antibacterial and molluscicidal phenolic acid from S. mombis. Planta Med. 1994;60:460-3.

13. Biplab A, Sudhir KY, Kshama R, Sandip KB, Subrata C. Black tea andtheaflavins assist healing of indomethacin-induced gastric ulceration in mice by antioxidative action. Evid Based Complem Alt Med. 2011;11:11-22.

14. Muhammed AVK, Thamotharan G, Sengottuvelu S, Haja-Sherief S, Sivakumar T. Evaluation of antiulcer activity of Ficus pumila L. leaf extract in albino rats. Glob J Res Med Plants Indig Med. 2012;1(8):340-51.

15. Puri D, Prabhu KM, Murthy PS. Mechanism of action of a hypoglycemic principle isolated from fenugreek seeds. Indian J Physiol Pharmacol. 2002;46(4):457-62.

16. Kumari S, Sinha M. Hypoglycemic Effect of Fenugreek Incorporated Therapeutic Food on Selected Diabetic Subjects, Department of Food and Nutrition, College of Home Science, Rajendra Agricultural University, Pusa, Samastipur, Bihar. 2012;848:125.

17. Bhatia K, Kaur M, Atif F, Ali M, Rehman H, Rahman S. Aqueous extract of ameliorates additive urotoxicity of buthionine sulfoximine and cyclophosphamide in mice. Food Chem. Toxicol. 2006;44(10):1744-50.

18. Priya VJR, Vijayalakshmi K. Studies on anti-oxidant activity of Trigonella foenum graecum seed using in vitro models. IJPSR. 2011;2(10):2704-8.

19. Yadav M, Lavania A, Tomar R. Complementary and comparative study on hypoglycemic and anti hyperglycemic activity of various extracts of Eugenia jambolana seed, Momordica charantia fruits, Gymnema sylvestre, and Trigonella foenum graecum seeds in rats. Appl Biochem Biotechnol. 2010;160(8): 2388-400.

20. Suja RP, Anuradha CV, Viswanathan P. Gastroprotective effect of fenugreek seeds (Trigonella foenum graecum) on experimental gastric ulcer in rats. J Ethnopharmacol. 2002;81(3):393-7.

21. Nirajan G, Syed BF, Shamreen N, Sudeshna P, Arnab KG, et al. Gastroprotective effect of Fenugreek 4-hydroxyisoleucine and trigonelline enriched fraction (TF4H (28\%)) Sugaheal $\circledast$ against indomethacin induced ulcer in male wistar rats. Journal of Pharmacy Research. 2016;10(6):351-64.

22. Madar Z, Shomer I. Polysaccharide composition of a gel fraction derived from fenugreek and its effect on starch digestion and bile acid absorption in rats. $J$ Agricultural Food Chemistry. 1990;38(7):1535-9.

23. Brinal FR, Pissurlenkar1, Premlata A, Samidha K, Renuka M, Manjusha G, et al. Treatment of Gastric Ulcers with Fenugreek Seed Extract; In vitro, In vivo and In silico Approaches. Indian J Pharm Sci. 2017;79(5):724-30.

24. Kheirandish R, Azari O, Samadieh H, Rasa Z. Protective effect of trigonella foenum graecum (fenugreek) seed extract on experimental intestinal ischemia/ reperfusion injury in rats. IJVS. 2011;6(1):37-46.

25. Kaviarasan S, Vijayalakshmi K, Anuradha CV. Polyphenol-rich extract of fenugreek seeds protect erythrocytes from oxidative damage. Plant Foods for Human Nutrition.2004;59(4):143-7. 
GRAPHICAL ABSTRACT

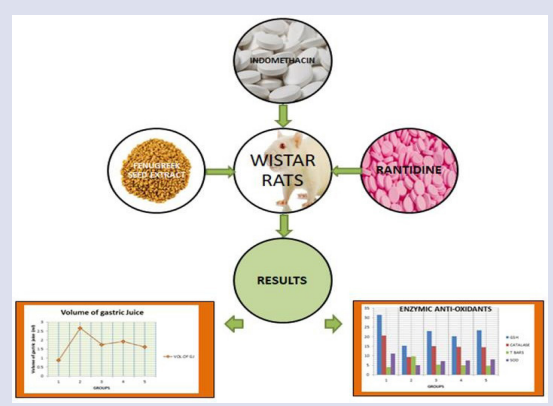

SUMMARY

- The study showed Trigonella foenum graceum was an effective anti-oxidative agent. Trigonella foenum graceum seed extract reduced the gastric ulcer index, volume of gastric juice and gastric acidity. Thus can be used effectively in the treatment of NSAID induced gastric ulcer.

Cite this article: Singaravelu S, Sankarapillai J, Chandrakumari AS, Sinha P. Effect of Trigonella foenum gracecum (Fenugreek) Seed Extract in Experimentally Induced Gastric Ulcer in Wistar Rats. Pharmacog J. 2018;10(6):1169-73. 